\title{
Elementary school students' perceptions about nature of scientific knowledge and some pseudoscientific ideas ${ }^{1}$
}

\author{
Behiye Bezir Akçay² \\ Seda Usta Gezer ${ }^{3}$ \\ Burak Kiras ${ }^{4}$
}

\begin{abstract}
In early childhood, people develop some beliefs that can affect the whole lives. Developing pseudoscientific beliefs can cause differences on child's nature of scientific knowledge. Giving importance on prevent gaining pseudoscientific knowledge may help qualified lifelong learning abilities. In this study, it was aimed to investigate the elementary school students' nature of scientific knowledge and views about some common pseudoscientific ideas. Also some variables' impacts on data collection tool scores were searched, too. The study was conducted on 2014-2015 educational year with $5^{\text {th }}, 6^{\text {th }}, 7^{\text {th }}$ and $8^{\text {th }}$ grade elementary school students. In the study, Nature of Scientific Knowledge Scale (NSKS) and eight statements were used to collect data. The aim of these eight statements was to figure out students' pseudoscientific ideas about evolution and nature of science. SPSS 20.00 programme was used to analyze data. It was found that girls' total scale scores were found higher than boys' total scores. Girls' amoral, parsimonious, testable and unified sub-dimension scores were also found higher than boys' scores. $7^{\text {th }}$ grade students showed higher total scale scores than the other grade students. Also, it was seen that $7^{\text {th }}$ grade students have more sophisticated knowledge about evolution than the nature of science features. At the end of the study the findings were discussed according to literature and some suggestions were given.
\end{abstract}

Keywords: Nature of Scientific knowledge; pseudoscientific ideas; elementary school students, gender.

\section{INTRODUCTION}

An important goal of education is helping students to become scientifically literate citizens that will allow them to become lifelong learners (National Research Council [NRC], 1996) because scientific literacy is a necessity for sustaining of contemporary democratic society (Hendrick, 1991). All science education reform efforts emphasize importance of scientific literacy which includes scientific knowledge, methods of science, and the nature of science (Holbrook \& Rannikmae,

\footnotetext{
${ }^{1}$ This article was presented at the 1st International Conference on Lifelong Education and Leadership, in Olomouc, Czech on October 29-31, 2015.

2 Associate Professor Dr., Istanbul University, Hasan Ali Yucel Education Faculty, Science Education Department, bbezir@gmail.com

3 Research Assistant Dr., Istanbul University, Hasan Ali Yucel Education Faculty, Science Education Department, sedausta@istanbul.edu.tr

$4 \quad$ Research Assistant, Abant Izzet Baysal University, Education Faculty, Science Education Department, burakkiras@gmail.com
} 
Bezir Akçay, B., Usta Gezer, S., \& Kiras, B. (2016). Elementary school students' perceptions about nature of scientific knowledge and some pseudoscientific ideas. International Journal of Human Sciences, 13(1), 1208-1221. doi:10.14687/ijhs.v13i1.3634

2009). The scientifically literate person understands the nature of scientific knowledge (Laugksch, 2000) that will give her/him an ability to distinguish from non-science (Liu, 2009).

Thirty-two Bologna signatory countries met in Lisbon-Prague in 2001. They concluded importance of globalization and new knowledge-driven economy as well as importance of lifelong learning. In 2010, the goal of education in Europe establish by "Education and Training 2010" work program which has lifelong learning component. Lifelong learning described as ongoing learning activity either formal or informal to improve knowledge, skills and competence (the Organization for Economic Co-operation and Development [OECD], 1996). Canadian Council of Ministers of Education (CCME) had a 2020 vision for lifelong learning from early childhood to adulthood. The CCME (1997) defined a scientifically literate person who "needs to acquire certain knowledge, skills, and attitudes; to develop inquiry, problem-solving and decision making abilities; to become a lifelong learner; and to maintain a sense of wonder about world (p.8)".

Organization for Economic Cooperation and Development (OECD) defined scientifically literate person who can "identify questions, to acquire new knowledge, to explain scientific phenomena, and to draw evidence-based conclusions about science related issues, understanding of the characteristic features of science as a form of human knowledge and enquiry" (OECD, 2006, p.12). According to Liu (2009) science literacy helps to reduce superstation. Walker and Hoekstra (2002) argue that scientifically literate person can distinguish science from pseudoscience and develop a skeptical view to discuss and decide about the issue.

Nature of science always becomes central component of scientific literacy (National Science Teacher association [NSTA], 1982). The nature of science typically has been defined as epistemology of science, science as a way of knowing, or the values and inherent in the development of scientific knowledge (Lederman, 1999). Understanding of the nature of science helps students to identify limitations, boundaries and fundamental assumptions of scientific knowledge, how science differs from other ways of knowing, distinguish between scientific and non scientific criteria as well as understand what pseudoscience is and what scientific knowledge is (Hodson, 2009; McComas, 1998).

Features of NOS have been explained from different researchers as scientific knowledge is empirically based, reliable and tentative, subjective to a degree, product of observation and inference as well as product of creative thinking, effected by social and cultural values, scientific laws and theories are different kinds of knowledge, scientists use many methods to develop knowledge (Akerson et al., 2012; NRC, 1996; American Association for the Advancement of Science [AAAS], 1993).

Learning science is lifelong process rather than a possibility (Billett, 2014). Students need to be prepared for lifelong learning about science because they need to know strength and limitations of science to identify differences between science and non-science (Anderson et al., 2011). When a student gains a pseudoscientific idea in early ages like elementary school period, it can be hard to change his or her scientific beliefs and even the way that is used for scientific research. This confusion can affect the student's lifelong learning abilities. A finding of a research can be interpreted differently depending on pseudoscientific ideas and this can be misleading for whole academicals processes. Pseudoscience include astrology, alchemy, parapsychology, sociobiology, psychoanalytic theory, Pyramidology, ghosts, crystal healing, reincarnation, telekinesis, telepathy, voodoo, magnetic healing, etc. (Lundström \& Jakobsson, 2009; Hodson, 2009). At this point from it can be seen that evolution is one common topic about having pseudoscientific ideas. Studies showed that when students' sophisticated understanding of nature of science related to their 
Bezir Akçay, B., Usta Gezer, S., \& Kiras, B. (2016). Elementary school students’ perceptions about nature of scientific knowledge and some pseudoscientific ideas. International Journal of Human Sciences, 13(1), 1208-1221. doi:10.14687/ijhs.v13i1.3634

acceptance of evolutionary theory (Sinatra et al., 2003). According to Sinatra, Southerland, McConaughy and Demastes (2003) "less-skilled reasoners were more likely to hold nonscientific beliefs initially, were less likely to be strongly committed to evolutionary statements, and were less likely to change their beliefs during instruction" (p. 512).

Research had been showed that Turkish students had lower performance on scientific literacy as well as to understand feature of scientific knowledge and how it differs from pseudoscientific beliefs compared to other OECD countries. Programme for International Student Assessment's (PISA) main domain in 2006 and 2015 was science literacy. In 2006, fifteen-year-old Turkish students had an average score of 424 on combined science literacy scale, lower than OECD average score of 500. Science literacy had a three subscale including identifying scientific issues (Turkish students score was 427), explaining phenomena scientifically (Turkish students score was 423), and using scientific evidence (Turkish students score was 417). PISA 2006 uses six proficiency levels to describe student performance in science literacy according to their scores. Level 1 was classified as lowest level of proficiency while level 6 was classified as the highest level of proficiency. In PISA 2006 Turkish students level they classified as level two which was very low (Baldi, Jin, Skemer, Green, \& Herget, 2007).

Helping students develop adequate conceptions of nature of science should be the main objective of science education (Kuliç et al., 2005). In this study, it was aimed to investigate the elementary school students' nature of scientific knowledge and views about some common pseudoscientific ideas about evolution and nature of science.

\section{METHOD}

\section{Participants}

The study was conducted in 2014-2015 education year. Participants includes $5^{\text {th }}$ grade $(N=42), 6^{\text {th }}$ grade $(71), 7^{\text {th }}$ grade $(\mathrm{N}=59)$ and $8^{\text {th }}$ grade $(\mathrm{N}=64)$ elementary students. Total 236 students were participated this study as seen in Table 1 .

Table 1: Demographic Data of the participants

\begin{tabular}{|l|l|l|l|}
\hline Grade levels & Girls & Boys & Total \\
\hline $\mathbf{5}$ & 16 & 26 & 42 \\
\hline $\mathbf{6}$ & 34 & 37 & 71 \\
\hline $\mathbf{7}$ & 30 & 29 & 59 \\
\hline $\mathbf{8}$ & 40 & 24 & 64 \\
\hline Total & 120 & 116 & 236 \\
\hline
\end{tabular}

\section{Data Collection Instruments}

The Nature of Scientific Knowledge Scale (NSKS; Rubba \& Andersen, 1978) was developed to asses understanding of the nature of scientific knowledge among students. It includes 48 statements; 24 positive and 24 negative items about scientific knowledge along a five-point Likert scale (i.e., from "strongly agree" to "strongly disagree"). The NSKS has six subscales of nature of scientific knowledge. Scientific knowledge is characterized as amoral, creative, developmental, parsimonious, testable and unified dimensions. Each of the six subscales includes 8 items. A maximum score of 40 was possible for each dimension and 240 points for the total NSKS score. 
Bezir Akçay, B., Usta Gezer, S., \& Kiras, B. (2016). Elementary school students’ perceptions about nature of scientific knowledge and some pseudoscientific ideas. International Journal of Human Sciences, 13(1), 1208-1221. doi:10.14687/ijhs.v13i1.3634

Turkish version of NSKS was translated and adapted into Turkish by Kılıç, Sungur, Çakıroğlu and Tekkaya (2005). The reliability of the Turkish version of the scale was found to be 0.74 by using Cronbach alpha. In this study cronbach alpha was found as .668. The sub-dimensions of the NSKS are defined in Table 2.

Table 2: Sub-dimension definitions of NSKS

\begin{tabular}{|l|l|}
\hline Sub-dimension & Definition \\
\hline Amoral & $\begin{array}{l}\text { Scientific knowledge provides people many capabilities, but does not provide } \\
\text { instruction on how to use them. Moral judgment can be passed on scientific } \\
\text { knowledge. A small amount scientific knowledge should not be judged good or } \\
\text { bad. }\end{array}$ \\
\hline Creative & $\begin{array}{l}\text { Scientific knowledge is a product of human imagination and intellect and } \\
\text { expresses the creativity of scientist.. }\end{array}$ \\
\hline Developmental & $\begin{array}{l}\text { The truth of scientific knowledge is beyond doubt. Scientific knowledge is } \\
\text { tentative. Scientific laws, theories and concepts may have to be changed when } \\
\text { new evidences are found. }\end{array}$ \\
\hline Parsimonious & $\begin{array}{l}\text { Scientific knowledge attempts to achieve simplicity of explanation as opposed to } \\
\text { complexity is stated as simply as possible. When theories explain observations } \\
\text { equally well, the simpler theory is chosen. }\end{array}$ \\
\hline Testable & $\begin{array}{l}\text { The evidence for scientific knowledge must be repeatable. Scientific knowledge } \\
\text { is capable of public empirical test. Consistency among test results is a } \\
\text { requirement for the acceptance of scientific knowledge. }\end{array}$ \\
\hline $\begin{array}{l}\text { Scientific knowledge helps people to understand the unity of nature. The laws, } \\
\text { theories and concepts of biology, chemistry and physics are related. Biology, } \\
\text { chemistry and physics are similar kinds of knowledge. }\end{array}$ \\
\hline
\end{tabular}

The other data collection tool was designed by the researchers as a survey. Eight statements of this survey were designed according to the related literature to figure out students' views about some pseudoscientific ideas in terms of evolution and nature of science (Table 3). Students gave yes or no answers to the questions according to their opinions on the statements.

Based on literature review, the eight statements were generated by using "Teaching about Evolution and the Nature of Science" book published from National Academy of Science (NAS) (1998). Students could choose Yes (1 point-I believe) and No (2 points- I don't believe) answers. Expected answer to items $2^{\text {th }}, 3^{\text {th }} 4^{\text {th }}, 5^{\text {th }}, 7^{\text {th }}$ were "Yes" and "No" to $1^{\text {th }}, 6^{\text {th }}, 8^{\text {th }}$ statements. The aim of these statements was to find out students' pseudoscientific ideas about evolution and the nature of science. 
Bezir Akçay, B., Usta Gezer, S., \& Kiras, B. (2016). Elementary school students’ perceptions about nature of scientific knowledge and some pseudoscientific ideas. International Journal of Human Sciences, 13(1), 1208-1221. doi:10.14687/ijhs.v13i1.3634

Table 3: Pseudoscientific Statements and the Sources Based on National Academy of Science

\begin{tabular}{|c|c|c|c|}
\hline No & Statement & Source & $\begin{array}{l}\text { Expected } \\
\text { Answer }\end{array}$ \\
\hline 1 & $\begin{array}{l}\text { Science gives answers to your all } \\
\text { questions }\end{array}$ & $\begin{array}{l}\text { "Science cannot answer all questions" } \\
\text { (NAS, 1998, p.67) }\end{array}$ & No \\
\hline 2 & $\begin{array}{l}\text { There are no knowledge resource } \\
\text { gives one hundred percent accurate } \\
\text { answers. }\end{array}$ & $\begin{array}{l}\text { "No one way of knowing can provide } \\
\text { all of the answers to the questions } \\
\text { that humans ask" (NAS, 1998, p.57) }\end{array}$ & Yes \\
\hline 3 & $\begin{array}{l}\text { People can believe science and be } \\
\text { religious at the same time. }\end{array}$ & $\begin{array}{l}\text { "Religions and science answer } \\
\text { different questions about the world. } \\
\text { Whether there is a purpose to the } \\
\text { universe or a purpose for human } \\
\text { existence are not questions for } \\
\text { science" (NAS, 1998, p.58). }\end{array}$ & Yes \\
\hline 4 & $\begin{array}{l}\text { Living things are descended from } \\
\text { common ancestor evolved } \\
\text { creatures. }\end{array}$ & $\begin{array}{l}\text { "Biological theory explaining the } \\
\text { process of descent with modification } \\
\text { of organisms from common } \\
\text { ancestors" (NAS, 1998, p.48). }\end{array}$ & Yes \\
\hline 5 & $\begin{array}{l}\text { Some changes can occur in living } \\
\text { things' genetically structures by } \\
\text { environmental condition effects and } \\
\text { they can transform to another thing. }\end{array}$ & $\begin{array}{l}\text { "Over time, evolutionary change } \\
\text { gives rise to new Species" (NAS, } \\
1998, \text { p.55). }\end{array}$ & Yes \\
\hline 6 & $\begin{array}{l}\text { Today's living things are in their } \\
\text { first form and didn't have any } \\
\text { transformation for millions years. }\end{array}$ & $\begin{array}{l}\text { "...evolution is most commonly } \\
\text { associated with the biological theory } \\
\text { explaining the process of descent } \\
\text { with modification of organisms from } \\
\text { common ancestors; evolution also } \\
\text { describes changes in the universe" } \\
\text { (NAS, 1998, p. 48). }\end{array}$ & No \\
\hline 7 & $\begin{array}{l}\text { Scientific knowledge can change in } \\
\text { the time. }\end{array}$ & $\begin{array}{l}\text { "Because all scientific ideas depend } \\
\text { on experimental and observational } \\
\text { confirmation, all scientific knowledge } \\
\text { is, in principle, subject to change as } \\
\text { new evidence becomes available" } \\
\text { (NAS, 1998, p.53). }\end{array}$ & Yes \\
\hline 8 & $\begin{array}{l}\text { Living things change their some } \\
\text { properties to show harmony to } \\
\text { environmental conditions and } \\
\text { transform these properties to next } \\
\text { generations. But they don't } \\
\text { transform to a new thing. }\end{array}$ & $\begin{array}{l}\text { Creation science is that "natural } \\
\text { selection can produce minor changes } \\
\text { within species, such as changes in } \\
\text { color or beak size, but cannot } \\
\text { generate new species from pre- } \\
\text { existing species" (NAS, 1998, p.57). }\end{array}$ & No \\
\hline
\end{tabular}

\section{Data Analysis}

Descriptive statistics on the six sub-dimensions and total score of the Nature of Scientific Knowledge Scale (NSKS) were investigated according to gender and grade levels. Also total scores and sub-dimensions of NSKS were compared with students' answers to eight statements about evolution and nature of science. SPSS 20.00 programme was used for analyze (Independent $t$ test 
Bezir Akçay, B., Usta Gezer, S., \& Kiras, B. (2016). Elementary school students’ perceptions about nature of scientific knowledge and some pseudoscientific ideas. International Journal of Human Sciences, 13(1), 1208-1221. doi:10.14687/ijhs.v13i1.3634

and ANOVA) of both the NSKS scale and eight statements about pseudoscientific ideas. The ideas can be seen from Table 3 .

\section{FINDINGS}

First of all, students' perceptions on nature of scientific knowledge and some common pseudoscientific ideas analyzed based on gender. Data from NSKS analyzed using Independent $\mathrm{t}$ test to find out any meaningful differences among sub-dimensions of the survey. Secondly, the findings analyzed based on grade level.

\section{NSKS finding by Gender}

Table 4: Independent $t$ test result on the six sub-dimensions and total score of the NSKS by gender

\begin{tabular}{llllllll}
\hline Sub-dimension & Groups & $\mathbf{N}$ & Mean & SD & df & t & p \\
\hline Amoral & Girls & 120 & 25.3667 & 3.82590 & 234 & 2.018 & .045 \\
\cline { 2 - 8 } & Boys & 116 & 24.3362 & 4.01940 & & & \\
\hline Developmental & Girls & 120 & 24.8917 & 3.76136 & 234 & -.115 & .909 \\
\cline { 2 - 8 } & Boys & 116 & 24.9483 & 3.82633 & & & \\
\hline Creative & Girls & 120 & 25.4000 & 4.21761 & 234 & -.025 & .980 \\
\cline { 2 - 8 } & Boys & 116 & 25.4138 & 4.32801 & & & \\
\hline Parsimonious & Girls & 120 & 23.1083 & 3.15375 & 234 & .366 & .715 \\
\cline { 2 - 8 } & Boys & 116 & 22.9397 & 3.89936 & & & \\
\hline Testable & Girls & 120 & 27.6500 & 4.74147 & 234 & 2.219 & .027 \\
\cline { 2 - 8 } & Boys & 116 & 26.2759 & 4.77054 & & & \\
\hline Unified & Girls & 120 & 27.6000 & 4.38753 & 234 & 2.585 & .010 \\
\cline { 2 - 8 } & Boys & 116 & 26.0517 & 4.80913 & & & \\
\hline Total & Girls & 120 & 154.0167 & 12.76681 & 234 & 2.372 & .019 \\
\cline { 2 - 8 } & Boys & 116 & 149.9655 & 13.47328 & & & \\
\hline
\end{tabular}

As seen from Table 4 girls' amoral, parsimonious, testable and unified sub-dimensions and total scale scores are higher than boys. It was also found according developmental and creative subdimensions boys' scores were higher than girls. The differences on amoral $\left(t_{234}=2.018 ; \mathrm{p} \leq .05\right)$, testable $\left(\mathrm{t}_{234}=2.219 ; \mathrm{p} \leq .05\right)$, unified $\left(\mathrm{t}_{234=} 2585 ; \mathrm{p} \leq .05\right)$ sub-dimensions and total score $\left(\mathrm{t}_{234=} 2.372\right.$; $\mathrm{p} \leq .05)$ were found statistically meaningful in favor of female students.

\section{Pseudoscientific Ideas Findings by Gender}

Eight different statements about nature of science and evolution analyzed using independent $\mathrm{t}$ test to find out if there are any meaningful differences based on gender. 
Bezir Akçay, B., Usta Gezer, S., \& Kiras, B. (2016). Elementary school students’ perceptions about nature of scientific knowledge and some pseudoscientific ideas. International Journal of Human Sciences, 13(1), 1208-1221. doi:10.14687/ijhs.v13i1.3634

Table 5: Independent $t$ test result on the statements about evolution and nature of science by gender

\begin{tabular}{llllllll}
\hline Ideas & Groups & $\mathbf{N}$ & Mean & SD & df & t & p \\
\hline 1 & Girls & 120 & 1.4333 & .49761 & 1.117 & 233.997 & .265 \\
\cline { 2 - 8 } & Boys & 116 & 1.3621 & .48268 & & & \\
\hline 2 & Girls & 120 & 1.5833 & .49507 & -.448 & 234 & .654 \\
\cline { 2 - 8 } & Boys & 116 & 1.6121 & .48939 & & & \\
\hline 3 & Girls & 120 & 1.8833 & .32237 & -1.528 & 219.465 & .128 \\
\cline { 2 - 9 } & Boys & 116 & 1.9397 & .23916 & & & \\
\hline 5 & Girls & 120 & 1.4750 & .50147 & .278 & 234 & .782 \\
\cline { 2 - 9 } & Boys & 116 & 1.4569 & .50030 & & & \\
\hline 6 & Girls & 120 & 1.2500 & .43483 & -.597 & 234 & .551 \\
\cline { 2 - 8 } & Boys & 116 & 1.2845 & .45313 & & & \\
\hline 7 & Girls & 120 & 1.6167 & .48824 & .072 & 234 & .942 \\
\cline { 2 - 8 } & Boys & 116 & 1.6121 & .48939 & & & \\
\hline 8 & Girls & 120 & 1.5333 & .50098 & -2.055 & 233.903 & .041 \\
\hline & Boys & 116 & 1.6638 & .47446 & & & \\
\hline & Girls & 120 & 1.1333 & .34136 & -1.822 & 221.750 & .070 \\
\hline & Boys & 116 & 1.2241 & .41882 & & & \\
\hline
\end{tabular}

Table 5 shows that "Scientific knowledge can change in the time" idea had significant difference in favor of boys $\left(\mathrm{t}_{233,903}=-2.055 ; \mathrm{p} \leq .05\right)$. These finding figures out those boys gave answer "yes "to idea "Scientific knowledge can change in the time" more than girls. This is the expected answer so they got statistically meaningful higher point from that idea. There were no meaningful differences found between girls' and boys' scores about other ideas.

\section{NSKS finding by Grade Level}

Results from six different sub-dimension of NSKS analyzed based on grade level to find out if there is any statistically difference among $5^{\text {th }}, 6^{\text {th }}, 7^{\text {th }}$ and $8^{\text {th }}$ grade students' perceptions about nature of scientific knowledge.

Table 6: Descriptive statistics on the six sub-dimensions and total score of the NSKS for school grades

\begin{tabular}{lllllllll}
\hline \multirow{2}{*}{$\begin{array}{l}\text { Sub- } \\
\text { dimension }\end{array}$} & \multicolumn{2}{l}{ 5th grade $\mathbf{( N = 4 2 )}$} & \multicolumn{2}{l}{ 6th grade $\mathbf{( N = 7 1 )}$} & \multicolumn{2}{l}{ 7th grade $\mathbf{( N = 5 9 )}$} & \multicolumn{2}{l}{ 8th grade $(\mathbf{N}=64)$} \\
\cline { 2 - 9 } & $\mathrm{M}$ & $\mathrm{SD}$ & $\mathrm{M}$ & $\mathrm{SD}$ & $\mathrm{M}$ & $\mathrm{SD}$ & $\mathrm{M}$ & $\mathrm{SD}$ \\
\hline Amoral & 24.7143 & 4.30703 & 24.7465 & 3.46706 & 25.2203 & 4.26723 & 24.7500 & 3.97213 \\
\hline Developmental & 24.5238 & 3.42329 & 24.3662 & 3.88491 & 25.3559 & 3.93815 & 25.3906 & 3.73154 \\
\hline Creative & 25.7857 & 4.14102 & 24.1549 & 4.19404 & 26.3729 & 4.61593 & 25.6562 & 3.83061 \\
\hline Parsimonious & 22.3333 & 3.71330 & 23.0000 & 3.76450 & 23.2542 & 3.82187 & 23.2969 & 2.82101 \\
\hline Testable & 27.2619 & 4.76296 & 25.6901 & 4.09038 & 28.0339 & 4.79930 & 27.2344 & 5.30870 \\
\hline Unified & 26.6667 & 4.69388 & 25.4085 & 4.58749 & 28.1864 & 4.47011 & 27.2969 & 4.52394 \\
\hline Total & 151.2857 & 12.68432 & 147.3662 & 10.98342 & 156.4237 & 14.73818 & 153.6250 & 13.05118 \\
\hline
\end{tabular}


Bezir Akçay, B., Usta Gezer, S., \& Kiras, B. (2016). Elementary school students’ perceptions about nature of scientific knowledge and some pseudoscientific ideas. International Journal of Human Sciences, 13(1), 1208-1221. doi:10.14687/ijhs.v13i1.3634

As seen from Table $6,7^{\text {th }}$ grade students got higher total scale scores than $5^{\text {th }}, 6^{\text {th }}$ and $8^{\text {th }}$ grade students. Amoral, creative, testable and unified sub-dimensions' scores were also found higher than the other grade students. Developmental and parsimonious sub-dimensions' scores of $8^{\text {th }}$ grade students were higher than the other grade students. The ANOVA test results can be seen from Table 7.

Table 7: ANOVA test results on the six sub-dimensions and total score of the NSKS for grade levels

\begin{tabular}{|c|c|c|c|c|c|c|}
\hline \multicolumn{2}{|l|}{ Sub-dimension } & \multirow{3}{*}{$\begin{array}{r}\text { Sum of Squares } \\
10.242\end{array}$} & \multirow{3}{*}{$\frac{\mathrm{df}}{3}$} & \multirow{4}{*}{$\begin{array}{r}\text { Mean } \\
\text { Square } \\
3.414 \\
15.742\end{array}$} & \multirow{3}{*}{$\begin{array}{c}\mathrm{F} \\
.217\end{array}$} & \multirow{3}{*}{$\begin{array}{l}\text { Sig. } \\
.885\end{array}$} \\
\hline \multirow{4}{*}{ Amoral } & & & & & & \\
\hline & Between Groups & & & & & \\
\hline & Within Groups & 3652.144 & 232 & & & \\
\hline & Total & 3662.386 & 235 & & & \\
\hline \multirow{3}{*}{ Developmental } & Between Groups & 53.755 & 3 & 17.918 & 1.255 & .291 \\
\hline & Within Groups & 3313.715 & 232 & 14.283 & & \\
\hline & Total & 3367.470 & 235 & & & \\
\hline \multirow{3}{*}{ Creative } & Between Groups & 176.348 & 3 & 58.783 & 3.331 & .020 \\
\hline & Within Groups & 4094.601 & 232 & 17.649 & & \\
\hline & Total & 4270.949 & 235 & & & \\
\hline \multirow{3}{*}{ Parsimonious } & Between Groups & 27.968 & 3 & 9.323 & .744 & .527 \\
\hline & Within Groups & 2905.879 & 232 & 12.525 & & \\
\hline & Total & 2933.847 & 235 & & & \\
\hline \multirow{3}{*}{ Testable } & Between Groups & 191.129 & 3 & 63.710 & 2.835 & .039 \\
\hline & Within Groups & 5212.719 & 232 & 22.469 & & \\
\hline & Total & 5403.847 & 235 & & & \\
\hline \multirow{3}{*}{ Unified } & Between Groups & 267.085 & 3 & 89.028 & 4.281 & .006 \\
\hline & Within Groups & 4824.797 & 232 & 20.797 & & \\
\hline & Total & 5091.881 & 235 & & & \\
\hline \multirow{3}{*}{ Total } & Between Groups & 2869.390 & 3 & 956.463 & 5.783 & .001 \\
\hline & Within Groups & 38370.457 & 232 & 165.390 & & \\
\hline & Total & 41239.847 & 235 & & & \\
\hline
\end{tabular}

From Table 7, it can be seen that creative $[\mathrm{F}(3-232)=3.331 ; \mathrm{p} \leq .05]$, testable $[\mathrm{F}(3-232)=2.835 ; \mathrm{p}$ $\leq .05]$, unified $[\mathrm{F}(3-232)=4.281 ; \mathrm{p} \leq .05]$ sub-dimensions and total score of NSKS [F (3$232)=5.783 ; \mathrm{p} \leq .05$ ] showed statistically meaningful differences according to grade level. For finding the meaningful differences between grade levels Post Hoc analyze (Tukey) were done. The meaningful results were given in Table 8 . 
Bezir Akçay, B., Usta Gezer, S., \& Kiras, B. (2016). Elementary school students’ perceptions about nature of scientific knowledge and some pseudoscientific ideas. International Journal of Human Sciences, 13(1), 1208-1221. doi:10.14687/ijhs.v13i1.3634

Table 8: Post Hoc Analyze results of grade levels that had significant differences on NSKS

\begin{tabular}{|c|c|c|c|c|c|}
\hline Dependent Variable & $\begin{array}{l}\text { (I) Grade } \\
\text { Level }\end{array}$ & $\begin{array}{l}\text { (J) Grade } \\
\text { Level }\end{array}$ & Mean Difference (I-J) & Std. Error & Sig. \\
\hline \multirow{7}{*}{ Creative } & \multirow{3}{*}{6.00} & 5.00 & -1.63078 & .81780 & .193 \\
\hline & & $\overline{7.00}$ & $-2.21795^{*}$ & .74008 & .016 \\
\hline & & 8.00 & -1.50132 & .72412 & .165 \\
\hline & \multirow{3}{*}{7.00} & 5.00 & .58717 & .84815 & .900 \\
\hline & & 6.00 & $2.21795^{*}$ & .74008 & .016 \\
\hline & & 8.00 & .71663 & .75823 & .781 \\
\hline & \multirow{3}{*}{6.00} & 5.00 & -1.57176 & .92273 & .324 \\
\hline \multirow{5}{*}{ Testable } & & 7.00 & $-2.34376^{*}$ & .83503 & .028 \\
\hline & & 8.00 & -1.54423 & .81703 & .235 \\
\hline & \multirow{3}{*}{7.00} & 5.00 & .77199 & .95697 & .851 \\
\hline & & 6.00 & $2.34376^{*}$ & .83503 & .028 \\
\hline & & 8.00 & .79952 & .85551 & .786 \\
\hline \multirow{9}{*}{ Unified } & \multirow{3}{*}{6.00} & 5.00 & -1.25822 & .88773 & .490 \\
\hline & & 7.00 & $-2.77799^{*}$ & .80336 & .004 \\
\hline & & 8.00 & -1.88842 & .78604 & .079 \\
\hline & \multirow{3}{*}{7.00} & 5.00 & 1.51977 & .92067 & .352 \\
\hline & & 6.00 & $2.77799^{*}$ & .80336 & .004 \\
\hline & & 8.00 & .88957 & .82306 & .702 \\
\hline & \multirow{3}{*}{6.00} & 5.00 & -3.91952 & 2.50346 & .400 \\
\hline & & $\overline{7.00}$ & $-9.05753^{*}$ & 2.26554 & .000 \\
\hline & & 8.00 & $-6.25880^{*}$ & 2.21668 & .026 \\
\hline \multirow{6}{*}{ Total } & \multirow{3}{*}{7.00} & 5.00 & 5.13801 & 2.59636 & .199 \\
\hline & & 6.00 & $9.05753^{*}$ & 2.26554 & .000 \\
\hline & & 8.00 & 2.79873 & 2.32109 & .624 \\
\hline & \multirow{3}{*}{8.00} & 5.00 & 2.33929 & 2.55383 & .796 \\
\hline & & 6.00 & $6.25880^{*}$ & 2.21668 & .026 \\
\hline & & 7.00 & -2.79873 & 2.32109 & .624 \\
\hline
\end{tabular}

In the Table 8 , according to the results of complementary post hoc test it can be seen that $6^{\text {th }}$ and $7^{\text {th }}$ grade students of creative, testable and unified sub-dimensions showed significant differences in favor of $7^{\text {th }}$ grade students. Also $6^{\text {th }}, 7^{\text {th }}$ and $8^{\text {th }}$ grade students' total scores were showed meaningful differences. The differences were between $6^{\text {th }}$ and $7^{\text {th }}$ grade students in favor of $7^{\text {th }}$ when $6^{\text {th }}$ and $8^{\text {th }}$ grade students in favor of $8^{\text {th }}$ grade students.

\section{Pseudoscientific Ideas Findings by Grade Level}

Eight statement adapted from "Teaching about Evolution and the Nature of Science" book (NAS, 1998) analyzed in terms of grade level to find out students' perceptions about any pseudoscientific ideas about nature of science and evolution. 
Bezir Akçay, B., Usta Gezer, S., \& Kiras, B. (2016). Elementary school students’ perceptions about nature of scientific knowledge and some pseudoscientific ideas. International Journal of Human Sciences, 13(1), 1208-1221. doi:10.14687/ijhs.v13i1.3634

Table 9: Descriptive statistics on the pseudoscientific statements for grade levels

\begin{tabular}{|c|c|c|c|c|c|c|c|c|}
\hline & \multicolumn{2}{|c|}{ 5th grade $(\mathrm{N}=42)$} & \multicolumn{2}{|c|}{ 6th grade $(\mathrm{N}=71)$} & \multicolumn{2}{|c|}{ 7th grade $(\mathrm{N}=59)$} & \multicolumn{2}{|c|}{ 8th grade $(\mathrm{N}=64)$} \\
\hline Statements & $\mathrm{M}$ & $\mathrm{SD}$ & $\mathrm{M}$ & SD & $\mathrm{M}$ & SD & $\mathrm{M}$ & SD \\
\hline 1 & 1.4048 & .49680 & 1.5493 & .50111 & 1.3390 & .47743 & 1.2813 & .45316 \\
\hline 2 & 1.5952 & .49680 & 1.6197 & .48891 & 1.5424 & .50248 & 1.6250 & .48795 \\
\hline 3 & 1.9524 & .21554 & 1.8873 & .31845 & 1.9153 & .28089 & 1.9063 & 29378 \\
\hline 4 & 1.5476 & .50376 & 1.3662 & .48519 & 1.5932 & .49545 & 1.4063 & .49501 \\
\hline 5 & 1.2857 & .45723 & 1.1549 & .36441 & 1.4407 & .50073 & 1.2188 & .41667 \\
\hline 6 & 1.6780 & .47127 & 1.5915 & .49505 & 1.6905 & 46790 & 1.5312 & .50297 \\
\hline 7 & 1.6190 & .49151 & 1.6197 & .48891 & 1.5593 & .50073 & 1.5938 & .49501 \\
\hline 8 & 1.2143 & .41530 & 1.1690 & .37743 & 1.2373 & .42907 & 1.1094 & 31458 \\
\hline
\end{tabular}

It can be seen from Table 9 that mostly $7^{\text {th }}$ grade students' mean scores given to statements were more scientifically. High item scores mean that students don't believe pseudoscientific ideas. This finding supports $7^{\text {th }}$ grade students' high NSKS scores. Students in different grade levels had higher mean scores in different statements. According to the findings; $5^{\text {th }}$ grades have informed knowledge about people can believe science and be religious at the same time ( $3^{\text {th }}$ statements). $6^{\text {th }}$ grades are more sophisticated about science doesn't give answers to all questions and some changes can occur in living things' genetically structures by environmental condition effects and they can transform to another thing $\left(1^{\text {th }}\right.$ and $7^{\text {th }}$ statements).

$7^{\text {th }}$ grades have more sophisticated knowledge about evolution than the invariance of science (statements 4, 5, 6 and 8). They believe "living things are descended from common ancestors evolved creatures", "some changes can occur in living things' genetically structures by environmental condition effects and they can transform to another thing", "today's living things are not in their first form and have any transformation for millions years" and "living things didn't change their some properties to show harmony to environmental conditions and transform these properties to next generations but they don't transform to a new thing." $8^{\text {th }}$ grade students have informed ideas about "there is no knowledge resource gives one hundred percent accurate answers." (Statement 2)

Meaningful statistically differences were found in $1^{\text {st }}[\mathrm{F}(3-232)=3.884 ; \mathrm{p} \leq .05], 4^{\text {th }}[\mathrm{F}(3-$ $232)=2.968 ; \mathrm{p} \leq .05]$, and $5^{\text {th }}[\mathrm{F}(3-232)=5.058 ; \mathrm{p} \leq .05]$ statements' answers according to grade levels. For finding the meaningful differences between grade levels Post Hoc analyze (Tukey) were done. The meaningful results were given in Table 10. 
Bezir Akçay, B., Usta Gezer, S., \& Kiras, B. (2016). Elementary school students' perceptions about nature of scientific knowledge and some pseudoscientific ideas. International Journal of Human Sciences, 13(1), 1208-1221. doi:10.14687/ijhs.v13i1.3634

Table 10: Post Hoc Analyze results of grade levels whom had significant differences on ideas

\begin{tabular}{|c|c|c|c|c|c|}
\hline Ideas & $\begin{array}{l}\text { (I) Grade } \\
\text { Level }\end{array}$ & $\begin{array}{l}\text { (J)Grade } \\
\text { Level }\end{array}$ & $\begin{array}{l}\text { Mean Difference (I- } \\
\mathrm{J} \text { ) }\end{array}$ & Std. Error & Sig. \\
\hline \multirow{6}{*}{1} & \multirow{3}{*}{6.00} & 5.00 & .14453 & .09379 & .415 \\
\hline & & 7.00 & .21031 & .08488 & .066 \\
\hline & & 8.00 & $.26805^{*}$ & .08305 & .008 \\
\hline & \multirow{3}{*}{8.00} & 5.00 & -.12351 & .09568 & .570 \\
\hline & & 6.00 & $-26805^{*}$ & .08305 & .008 \\
\hline & & 7.00 & -.05773 & .08696 & .911 \\
\hline \multirow{6}{*}{4} & \multirow{3}{*}{6.00} & 5.00 & -18142 & .09611 & .236 \\
\hline & & 7.00 & $-.22702^{*}$ & .08698 & .047 \\
\hline & & 8.00 & -.04005 & .08510 & .965 \\
\hline & \multirow{3}{*}{7.00} & 5.00 & .04560 & .09968 & .968 \\
\hline & & 6.00 & $.22702^{*}$ & .08698 & .047 \\
\hline & & 8.00 & .18697 & .08911 & .157 \\
\hline \multirow{9}{*}{5} & \multirow{3}{*}{6.00} & 5.00 & -.13078 & .08414 & .407 \\
\hline & & 7.00 & $-.28575^{*}$ & .07615 & .001 \\
\hline & & 8.00 & -.06382 & .07450 & .827 \\
\hline & \multirow{3}{*}{7.00} & 5.00 & .15496 & .08727 & .288 \\
\hline & & 6.00 & $.28575^{*}$ & .07615 & .001 \\
\hline & & 8.00 & $.22193 *$ & .07801 & .025 \\
\hline & \multirow{3}{*}{8.00} & 5.00 & -.06696 & .08584 & .863 \\
\hline & & 6.00 & .06382 & .07450 & .827 \\
\hline & & 7.00 & $-.22193 *$ & .07801 & .025 \\
\hline
\end{tabular}

In the Table 10, according to the results of post hoc test it can be seen that for $1^{\text {st }}$ idea $6^{\text {th }}$ and $8^{\text {th }}$ grade students' points showed significant differences in favor of $6^{\text {th }}$ grade students. For $4^{\text {th }}$ idea, $6^{\text {th }}$ and $7^{\text {th }}$ grade students' points showed significant differences in favor of $7^{\text {th }}$ grade students. For $5^{\text {th }}$ idea; $6^{\text {th }}, 7^{\text {th }}$ and $8^{\text {th }}$ grade students' points showed meaningful differences in favor of $7^{\text {th }}$ grade students.

Table 11: Statistically meaningful t-test results of six sub-dimensions and total score of NSKS according to the yes or no answers of questions

\begin{tabular}{|c|c|c|c|c|c|c|c|c|}
\hline Ideas & Score & Groups & $\mathbf{N}$ & Mean & SD & $\mathbf{t}$ & df & $\mathrm{p}$ \\
\hline \multirow[t]{2}{*}{1} & Developmental & 1.00 & 142 & 25.0423 & 3.80159 & \multirow{2}{*}{.612} & \multirow{2}{*}{234} & \multirow{2}{*}{.541} \\
\hline & & 2.00 & 94 & 24.7340 & 3.77364 & & & \\
\hline \multirow[t]{2}{*}{2} & Developmental & 1.00 & 95 & 24.7053 & 3.80334 & \multirow{2}{*}{-.713} & \multirow{2}{*}{234} & \multirow{2}{*}{.477} \\
\hline & & 2.00 & 141 & 25.0638 & 3.78005 & & & \\
\hline \multirow[t]{2}{*}{3} & Amoral & 1.00 & 21 & 25.0476 & 4.65270 & \multirow{2}{*}{.228} & \multirow{2}{*}{234} & \multirow{2}{*}{.820} \\
\hline & & 2.00 & 215 & 24.8419 & 3.88420 & & & \\
\hline \multirow[t]{2}{*}{4} & Total & 1.00 & 126 & 149.0714 & 12.72489 & \multirow{2}{*}{-3.768} & \multirow{2}{*}{234} & \multirow{2}{*}{.000 } \\
\hline & & 2.00 & 110 & 155.4091 & 13.07725 & & & \\
\hline \multirow[t]{2}{*}{5} & Total & 1.00 & 173 & 151.2659 & 13.21815 & \multirow{2}{*}{-1.463} & \multirow{2}{*}{234} & \multirow[t]{2}{*}{.145} \\
\hline & & 2.00 & 63 & 154.1111 & 13.20693 & & & \\
\hline \multirow[t]{2}{*}{6} & Total & 1.00 & 91 & 150.7473 & 13.68502 & \multirow{2}{*}{-1.175} & \multirow{2}{*}{234} & \multirow{2}{*}{.241} \\
\hline & & 2.00 & 145 & 152.8276 & 12.94827 & & & \\
\hline \multirow[t]{2}{*}{7} & Developmental & 1.00 & 95 & 24.4947 & 3.61402 & \multirow{2}{*}{-1.418} & \multirow{2}{*}{234} & \multirow{2}{*}{.158} \\
\hline & & 2.00 & 141 & 25.2057 & 3.88315 & & & \\
\hline \multirow[t]{2}{*}{8} & Total & 1.00 & 194 & 152.6443 & 13.15993 & \multirow{2}{*}{1.547} & \multirow{2}{*}{234} & \multirow{2}{*}{.123} \\
\hline & & 2.00 & 42 & 149.1667 & 13.43261 & & & \\
\hline
\end{tabular}


Bezir Akçay, B., Usta Gezer, S., \& Kiras, B. (2016). Elementary school students' perceptions about nature of scientific knowledge and some pseudoscientific ideas. International Journal of Human Sciences, 13(1), 1208-1221. doi:10.14687/ijhs.v13i1.3634

From Table 11, the ideas and related scores can be seen. $1^{\text {st }}, 2^{\text {nd }}$ and $7^{\text {th }}$ ideas were related with developmental sub-dimension score. $3^{\text {th }}$ idea was related with amoral sub-dimension score. The other ideas $(4,5,6$, and 8$)$ were related with total score. t-test results showed that just $4^{\text {th }}$ idea $\left(t_{234}=\right.$ $-3,768 ; \mathrm{p} \leq .05)$ had significant meaningful differences between given yes and no answers in favor of No answers. This finding shows that students have common wrong beliefs about "Living things are descended from common ancestor evolved creatures." The other statements didn't show any significant differences according to dependent sub-dimension or total NSKS scores.

\section{RESULTS and DISCUSSION}

Students need to know how to distinguish between faith and knowledge, science from religion and pseudoscience to become lifelong learners. Source of scientific knowledge and evidence to support the knowledge is known but source of pseudoscience and the evidence is always vague. Students need to know that scientific knowledge is based on empirical evidence and it can be subject to change therefore it is tentative but still scientific knowledge is durable. Kilıç et al. (2005) found in their studies that between $9^{\text {th }}$ grade students girls got higher scores from all sub-dimensions similar to our study. The differences between girls' and boys' scores could depend on the difference between the interpretation of empirical evidences, usage of scientific method, perspectives to science and background experiences. Also Spector, Strong and La Porta (2002) defines pseudoscience as an outgrowth of the human characteristic called, "safety seeking". This could also be another reason between girls and boys scores considering their age group properties. Boys gave answer "yes" to idea "Scientific knowledge can change in the time" more than girls. There weren't found any differences between boys and girls when ideas about evolution and the invariance of science. The sophisticated ideas of boys about this statement could be the reason of their abilities like observation, organization and arrangement. Şimşek and Tezcan (2008) points out that student who have these abilities from younger ages start their academic life with these properties and use them especially in science courses. This result might be a reason of male students' reasoning skills in the science issues.

Sinatra (2005) and McComas (1998) discussed that learner's conceptual change process are effected by one's epistemological beliefs which has a major impact of whether to consider alternative knowledge rather than solely affected by structure of instructional strategies in which students engage. Sinatra et al. (2003) argued that "epistemological beliefs are changeable; they are related to a learner's education" (p. 514). Mostly $7^{\text {th }}$ grade students showed less pseudoscientific ideas similar to their NSKS scale scores. $7^{\text {th }}$ grade students' amoral, creative, testable and unified sub-dimensions' scores were also higher than the other grade students. This two finding could support each other and could be told as pseudoscientific ideas were related with nature of science. Yenice and Sağlam (2010) figured out in their study that $8^{\text {th }}$ grade students' generally hold double-minded and unsatisfactory views on the nature of scientific knowledge and similar decrease can be seen in this study. Also Kaya et al. (2013) found that half of 6,7 and 8 grade students believe scientific knowledge can be changed in time whereas the other half don't believe. These are all can be the result of missing nature of scientific knowledge of different grade level students.

Researchers have suggested that explicit NOS instruction must address students' prior knowledge and beliefs (McComas, 1998; Lederman, 1999). However goal of this instructional method is not to change learner's religious beliefs or to convince them accept theory of evolution. Instead to give students an opportunity to justify their beliefs and knowledge so they could compare and think deeply about theory of evolution. This would give them an opportunity to change their conceptual view (Sinatra et al., 2003). By this way more students who don't show any sub-dimension properties 
Bezir Akçay, B., Usta Gezer, S., \& Kiras, B. (2016). Elementary school students’ perceptions about nature of scientific knowledge and some pseudoscientific ideas. International Journal of Human Sciences, 13(1), 1208-1221. doi:10.14687/ijhs.v13i1.3634

can change their conceptual views. Different sub-dimensions represent different perspectives to scientific ideas and beliefs. Students and teachers must be informed about the nature of scientific knowledge that it is partially a product of human creativity and imagination, it is tentative, it is partially a function of human subjectivity, and scientific knowledge necessarily involves a combination of observation and inference (Kılıç et al., 2005). All students should figure out diversities depending on their own perspectives. Believing or not believing a pseudoscientific idea gives opinion about nature of science and self lifelong learning abilities which are important for all levels of education.

\section{SUGGESTIONS}

For protecting elementary school students from pseudoscientific ideas, nature of science should be integrated into courses and making science by doing may be one of the ideal ways. By the way student can ask own question, investigate, observe, make experiment, discuss with friends and can find the correct solution by-self. A knowledge which is gained by this scientific way may protect the student to believe a superstition. Giving place to inquiry and problem based approaches more in courses, making some courses with outdoor activities, teaching scientific process skills with the reasons, letting students to gain experiences and teaching to students nature of science from lower ages may help them to follow scientific way strongly instead of digress to pseudoscientific ideas.

\section{REFERENCES}

Akerson, V., Donnelly, L. A., Riggs, M. L. \& Eastwood, J. L. (2012). Developing a community of practice to support preservice elementary teachers' nature of science instruction. International Journal of Science Education, 34(9), 1371-1392.

American Association for the Advancement of Science (AAAS) (1993). Benchmarks for scientific literacy. Oxford, UK: Oxford University Press.

Anderson, W. A.; Banerjee, U.; Drennan, C.L.; Elgin, S. C. R.; Epstein, I. R.; Handelsman, J.; Hatfull, G. F.; Losick , R.; O’Dowd, D. K.; Olivera, B. M.; Strobel, S. A.; Walker, G. C.; \& Warner, I. M. (2011). Science education. Changing the culture of science education at research universities. 331, 152-153. http://escholarship.org/uc/item/1p37m7xw education forum.

Baldi, S., Jin, Y., Skemer, M., Green, P.J., \& Herget, D. (2007). Highlights from PISA 2006: Performance of U.S. 15-Year-Old Students in Science and Mathematics Literacy in an International Context (NCES 2008-016). NCES. Washington, DC.

Billett, S. (2014). Conceptualizing lifelong learning in contemporary times. In Halttunen, T., Koivisto, N., \& Billett, S. (Eds.), Promoting, assessing, recognizing and certiffing lifelong learning (1935). Netherlands: Springer.

Canadian Council of Ministers of Education (CCME) (1997). The Common Framework of Science Learning Outcomes $K$ to 12 . Toronto, Ontario.

Hendrick, R. (1991). Biology, history and Louis Pasteur: A new approach to teaching science. American Biology Teacher, 53(8), 467-478.

Hodson, D. (2009). Teaching and learning about science. Netherlands: Sense Publishers.

Holbrook, J. \& Rannikmae, M. (2009). The meaning of scientific literacy. International Journal of Environmental \& Science Education, 4(3), 275-288.

Kaya, V. H., Afacan, Ö., Polat, D. ve Urtekin, A. (2013). İlköğretim öğrencilerinin bilim insanı ve bilimsel bilgi hakkındaki görüssleri (Kırşehir ili örneği). Ahi Evran Üniversitesi Kırşsehir Eŭitim Fakültesi Dergisi (KEFAD), 14(1), 305-325. 
Bezir Akçay, B., Usta Gezer, S., \& Kiras, B. (2016). Elementary school students’ perceptions about nature of scientific knowledge and some pseudoscientific ideas. International Journal of Human Sciences, 13(1), 1208-1221. doi:10.14687/ijhs.v13i1.3634

Kılıç, K., Sungur, S., Çakıroğlu, J. \& Tekkaya, C. (2005). Ninth grade students' understanding of the nature of scientific knowledge. Hacettepe Üniversitesi Ë̈itim Fakültesi Dergisi, 28, 127-133.

Laugksch, R. C. (2000). Scientific literacy: a conceptual overview. Science Education, 84(1), 71-94.

Lederman, N, G., (1999). Teachers' understanding of the nature of science and classroom practice: Factors that facilitate or impede the relationship. Journal of Research in Science Teaching, 36(8), 916-929.

Liu, X. (2009). Beyond Science Literacy: Science and the Public. International Journal of Environmental \& Science Education, 4(3), 301-311.

Lundström, M. \& Jakabsson, A. (2009). Students' ideas regarding science and pseudoscience in relation to the human body and health. $\mathrm{NorD} \imath \mathrm{Na}, 5(1), 3-7$.

McComas, W. F. (1998). The Nature of Science in Science Education Rationales and Strategies. Dordrecht: Kluwer Academic Publishers.

The National Academy of Sciences (NAS) (1998). Teaching About Evolution and the Nature of Science. Washington, DC:National Academy Press Available at: http://www.nap.edu/catalog.php?record_id=5787 (accessed April 14, 2014).

National Research Council (NRC) (1996). National science standards. Washington, DC: National Academy Press.

National Science Teachers Association (NSTA) (1982). Science-technology-society: Science education for the 1980s. (An NSTA position statement). Washington, DC: Author.

Organization for Economic Cooperation and Development (OECD) (1996). Lifelong Learning for All, OECD, Paris.

Organization for Economic Cooperation and Development (OECD). (2006). Assessing Scientific, Reading and Mathematical Literacy: A Framework for PISA 2006. Paris: Author.

Rubba, P. A., \& Anderson, H. O. (1978). Development of an instrument to assess secondary school students' understanding of the nature of scientific knowledge. Science Education, 62(4), 449-458.

Sinatra, G. M., Southerland, S. A., McConaughy, F., \& Demastes, J. (2003). Intentions and beliefs in students' understanding and acceptance of biological evolution. Journal of Research in Science Teacbing, 40(5), 510-528.

Sinatra, G. M. (2005). The "Warming Trend" in conceptual change research: The legacy of Paul R. Pintrich. Educational Psychologist, 40(2), 107-115.

Spector, B., Strong, P., \& La Porta, T. (2002). Teaching the nature of science as an element of science, technology and society. In The Nature of Science in Science Education (pp. 267-276). Springer Netherlands.

Şimşek, C. L., \& Tezcan, R. (2008). Çocukların fen kavramlarıly ilgili düşüncelerinin gelişimini etkileyen faktörler. İlkögretim Online, 7(3).

Yenice, N., \& Saydam, G. (2010). 8th grade students' science attitudes and views about nature of scientific knowledge. Journal of Qafqaz. University, 29(1), 89-97.

Walker, W. R. \& Hoekstra, S. J. (2002). Science education is no guarantee of skepticism. Skeptic, 9(3), 24-27. 